Table 2. Example of relationships between designations of enzymes, phenotypes, alleles and genotypes for a human class $\mathrm{Mu}$ glutathione transferase (GST)

\begin{tabular}{|c|c|c|c|}
\hline Enzyme & Phenotype & Allele & Genotype(s) \\
\hline GSTM1a-1a & GSTM1 A & $G S T M I^{*} A$ & $\begin{array}{l}G S T M I^{*} A / G S T M I^{*} A \\
G S T M I^{*} A / G S T M I^{*} O\end{array}$ \\
\hline GSTMla-lb & GSTM1 A,B & & $G S T M I^{*} A / G S T M I^{*} B$ \\
\hline GSTM1b-1b & GSTM1 B & $G S T M 1^{*} B$ & $\begin{array}{l}G S T M l^{*} B / G S T M l^{*} B \\
G S T M l^{*} B / G S T M l^{*} O\end{array}$ \\
\hline- & GSTM1 null & $G S T M I^{*} O$ & $G S T M 1^{*} O / G S T M 1^{*} O$ \\
\hline
\end{tabular}

This system for naming glutathione transferases can easily be extended to other mammalian species. When it is necessary to distinguish enzymes from different species, the designation could be prefixed with a lower case letter showing its origins. Thus, the human and rat class $\mathrm{Pi}$ glutathione transferases may be distinguished as hGSTP1-1 and rGSTP1-1. A more complete prefix for species identification should be based on Latin names as adopted for homologous genes, e.g. HSA for Homo sapiens, RNO for Rattus norvegicus or MMU for Mus musculus [1].

The authors of this paper will serve as a consulting group and assist in naming new enzyme forms that may be discovered.

Bengt MANNERVIK*, Yogesh C. AWASTHI†,

Philip G. BOARD $\ddagger$ John D. HAYES§, Carmine DI ILIO", Brian KETTERER $\uparrow$, Irving LISTOWSKY**,

Ralf MORGENSTERN $\dagger$, Masami MURAMATSU $\ddagger$,

William R. PEARSON§§, Cecil B. PICKETT"\|, Kiyomi SATOףף, Mikael WIDERSTEN* and C. Roland WOLF***

*Department of Biochemistry, Biomedical Center, Uppsala University, Box 576, S-751 23 Uppsala, Sweden

†Department of Human Biological Chemistry and Genetics, University of Texas Medical Branch, Galveston, TX 77550, U.S.A.

$\ddagger$ Molecular Genetics Group, Division of Clinical Sciences,

John Curtin School of Medical Research, P.O. Box 334,

Canberra, A.C.T. 2601, Australia

§University Department of Clinical Chemistry, Royal

Infirmary, Edinburgh EH3 9YW, U.K.

Istituto di Scienze Biochimiche, Facoltà di Medicina,

Università 'G. D'Annunzio', I-66100 Chieti, Italy

-Cancer Research Campaign, Molecular Toxicology Group,

University College and Middlesex Hospital Medical School, Windeyer Building, Cleveland Street, London W1P 6DB, U.K.

**Department of Biochemistry, Albert Einstein College of

Medicine, Bronx, NY 10461, U.S.A.

††Department of Toxicology, The Karolinska Institute, Box 60400, S-104 01 Stockholm, Sweden

$\ddagger \ddagger$ Department of Biochemistry, University of Tokyo, Faculty of Medicine, Tokyo 113, Japan

\$Department of Biochemistry, University of Virginia, Box

440, Charlottesville, VA 22908, U.S.A.

|| ||Merck Frosst Centre for Therapeutic Research, P.O. Box

1005, Pointe Claire-Dorval, Quebec H9R 4P8, Canada

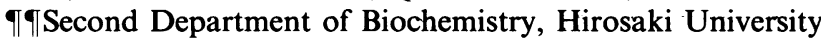

School of Medicine, Hirosaki 036, Japan

***Molecular Pharmacology Group, Imperial Cancer Research

Fund, Hugh Robson Building, George Square, Edinburgh EH8 9XD, U.K.

1. Shows, T. B., McAlpine, P. J., Boucheix, C., Collins, F. S., Conneally, P. M., Frezal, J., Gershowitz, H., Goodfellow, P. N., Hall, J. G., Issit, P., Jones, C. A., Knowles, B. B., Lewis, M., McKusick, V. A., Meisler, M., Morton, N. E., Rubinstein, P., Schanfield, M. S.,
Schmickel, R. D., Skolnick, M. H., Spence, M. A., Sutherland, G. R., Traver, M., Van Cong, N. \& Willard, H. F. (1987) Cytogenet. Cell. Genet. 46, 11-28

2. Mannervik, B. \& Danielson, U. H. (1988) CRC Crit. Rev. Biochem. 23, 283-337

3. Hayes, J. D., Pickett, C. B. \& Mantle, T. J. (eds.) (1990) Glutathione $S$-Transferases and Drug Resistance, Taylor \& Francis, London

4. Sies, H. \& Ketterer, B. (eds.) (1988) Glutathione Conjugation: Mechanisms and Biological Significance, Academic Press, London

5. Tu, C.-P. D. \& Qian, B. (1986) Biochem. Biophys. Res. Commun. 141, 229-237

6. Board, P. G. \& Webb, G. C. (1987) Proc. Natl. Acad. Sci. U.S.A. 84, 2377-2381

7. Hayes, J. D., Kerr, L. A. \& Cronshaw, A. D. (1989) Biochem. J. 246, 437-445

8. Rhoads, D. M., Zarlengo, R. P. \& Tu, C.-P. D. (1987) Biochem. Biophys. Res. Commun. 145, 474-481

9. DeJong, J. L., Chang, C.-M., Whang-Peng, J., Knutsen, T. \& Tu, C.-P. D. (1988) Nucleic Acids Res. 16, 8541-8554

10. Seidegård, J., Vorachek, W. R., Pero, R. W. \& Pearson, W. R. (1988) Proc. Natl. Acad. Sci. U.S.A. 85, 7293-7297

11. Vorachek, W. R., Pearson, W. R. \& Rule, G. S. (1991) Proc. Natl. Acad. Sci. U.S.A. 88, 4443-4447

12. Campbell, E., Takahashi, Y., Abramovitz, M., Peretz, M. \& Listowsky, I. (1990) J. Biol. Chem. 265, 9188-9193

13. Kano, T., Sakai, M. \& Muramatsu, M. (1987) Cancer Res. 47, $5626-5630$

14. Ahmad, H., Wilson, D. E., Fritz, R. R., Singh, S. V., Medh, R. D., Nagle, G. T., Awasthi, Y. C. \& Kurosky, A. (1990) Arch. Biochem. Biophys. 278, 398-408

15. Board, P. G., Webb, G. C. \& Coggan, M. (1989) Ann. Human Genet. 53, 205-213

16. Meyer, D. J., Coles, B., Pemble, S. E., Gilmore, K. S., Fraser, G. M. \& Ketterer, B. (1991) Biochem. J. 274, 409-414

17. DeJong, J. L., Morgenstern, R., Jörnvall, H., DePierre, J. W. \& Tu, C.-P. D. (1988) J. Biol. Chem. 263, 8430-8436

18. DeJong, J. L., Mohandas, T. \& Tu, C.-P. D. (1990) Genomics 6, 379-382

19. De Jong, J. L., Mohandas, T. \& Tu, C.-P. D. (1991) Biochem. Biophys. Res. Commun. 180, 15-22

Received 18 October 1991

\section{Pyrophosphatase-induced $\mathrm{Ca}^{2+}$ release is unrelated to the spontaneous release from inositol 1,4,5-trisphosphate-sensitive $\mathrm{Ca}^{2+}$ stores}

Ins $(1,4,5) P_{3}$-sensitive intracellular $\mathrm{Ca}^{2+}$ stores become more sensitive to $\operatorname{Ins}(1,4,5) P_{3}$ as they load with $\mathrm{Ca}^{2+}[1-3]$. Such behaviour could be important for generating 'quantal' $\mathrm{Ca}^{2+}$ release, $\mathrm{Ca}^{2+}$ entry and $\mathrm{Ca}^{2+}$ oscillations $[1,4,5]$. Once the pools reach a critical $\mathrm{Ca}^{2+}$ content, they become sensitive to the basal level of $\operatorname{Ins}(1,4,5) P_{3}$ and release their $\mathrm{Ca}^{2+}$ to produce a spike [1]. Precipitating anions such as $\mathrm{P}_{\mathrm{i}}$ increase the $\mathrm{Ca}^{2+}$-accumulating capacity of the pools and thereby prevent the spike [1]. However, a spontaneous $\mathrm{Ca}^{2+}$ release has been reported in the presence of 5 mM-pyrophosphate $\left(\mathrm{PP}_{1}\right)$ in bovine chromaffin cells [6]. We now report that such $\mathrm{Ca}^{2+}$ release also occurs in rat hepatocytes, and that this release is unrelated to the spontaneous $\mathrm{Ca}^{2+}$ release from overloaded $\operatorname{Ins}(1,4,5) P_{3}$-sensitive pools that we earlier reported.

Fig. 1(a) illustrates how permeabilized hepatocytes sequestered $\mathrm{Ca}^{2+}$ in the presence of $5 \mathrm{mM}-\mathrm{PP}_{1}$. After the initial phase of $\mathrm{Ca}^{2+}$ sequestration when the medium free $\left[\mathrm{Ca}^{2+}\right]$ fell to $50 \mathrm{nM}$, the free $\left[\mathrm{Ca}^{2+}\right]$ spontaneously rose to a new steady state after a latency. A large $\mathrm{Ca}^{2+}$ spike occurred when additional $\mathrm{Ca}^{2+}(40 \mathrm{nmol})$ and 

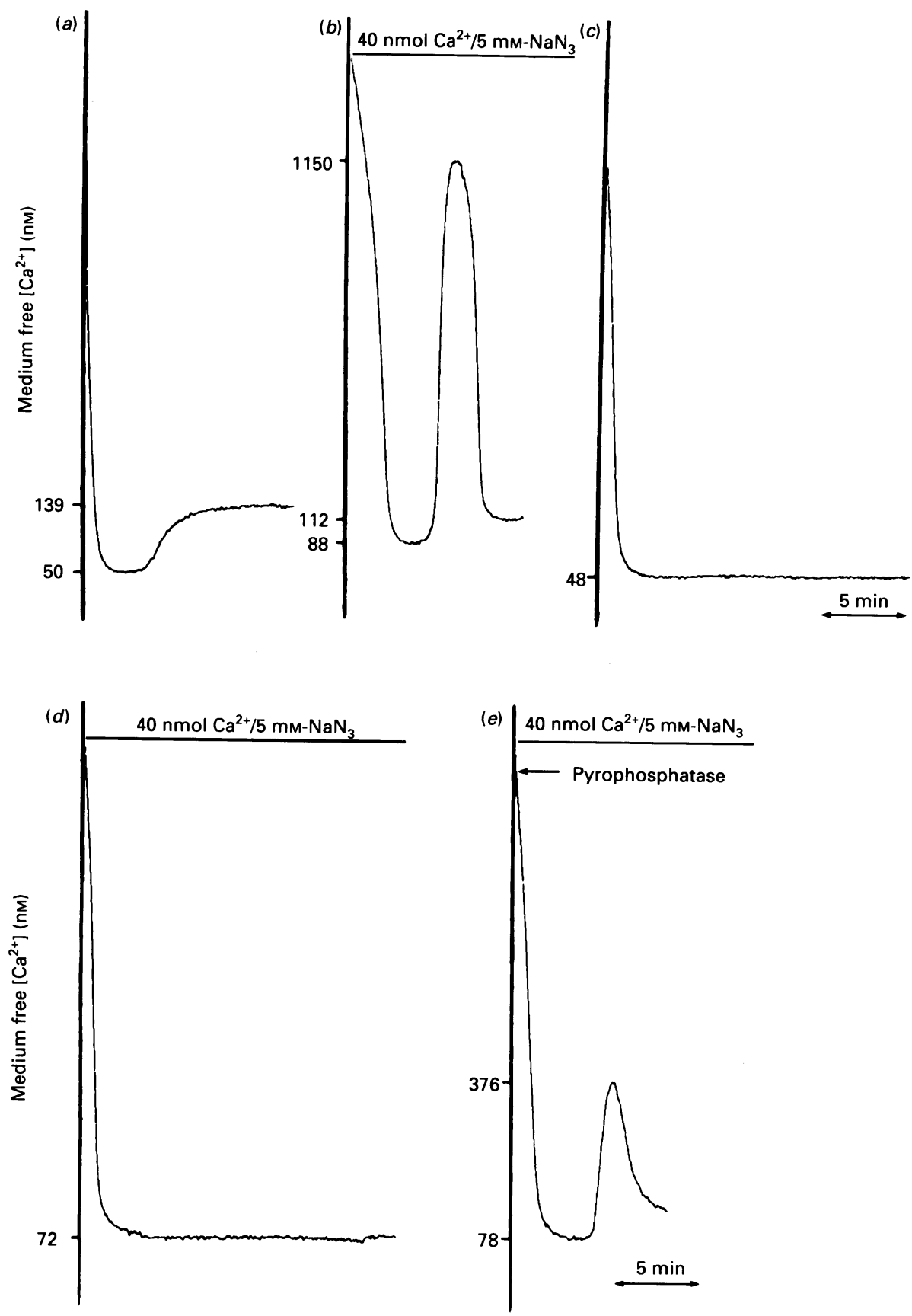

Fig. 1. $\mathrm{Ca}^{2+}$ uptake and release by permeabilized rat hepatocytes

Traces $(a),(b)$ and $(c)$ illustrate how the free $\left[\mathrm{Ca}^{2+}\right]$ changed with time when permeabilized hepatocytes $\left(1.0^{7} / \mathrm{ml}\right)$ were incubated in the presence of $5 \mathrm{mM}-\mathrm{PP}_{\mathrm{i}}(a$ and $b)$ or methylene diphosphonic acid $(c)$ in an assay medium as described in [1]. Trace $(d)$ illustrates that no spike occurred when the cells were washed twice after permeabilization to remove the cytosolic pyrophosphatases and (e) shows how the addition of $250 \mathrm{~m}$-unit of pyrophosphatase from yeast to these washed cells restored the spike. The assay medium in $(b),(d)$ and $(e)$ was supplemented with $5 \mathrm{~mm}^{-\mathrm{NaN}_{3}}$ and $40 \mathrm{nmol} \mathrm{Ca}^{2+}$, as indicated.

$\mathrm{NaN}_{3}(5 \mathrm{~mm})$ were added at the beginning of the loading period (Fig. $1 b$ ).

The following observations indicate that the activity of a cytosolic pyrophosphatase was responsible for the spontaneous $\mathrm{Ca}^{2+}$ spike in the presence of $\mathrm{PP}_{\mathrm{i}}$ : (1) The spike occurred later when the $\left[\mathrm{PP}_{\mathrm{i}}\right]$ was increased from 5 to $10 \mathrm{mM}$. Also, the rise in $\left[\mathrm{Ca}^{2+}\right]$ was reversed by a subsequent addition of $5 \mathrm{mM}-\mathrm{PP}_{\mathrm{i}}$ (data not shown). (2) No spontaneous $\mathrm{Ca}^{2+}$ release occurred if $5 \mathrm{~mm}$ methylene diphosphonic acid, which is not hydrolysed by the pyrophosphatase [7], was used as precipitating anion (Fig. 1c). (3) Diluting the cells and their cytosolic pyrophosphatases increased the latency before the spike (data not shown). (4) Cells from which the cytosolic pyrophosphatases were washed away after permeabilization showed no spontaneous release (Fig. 1d), while adding pyrophosphatase from yeast $(250 \mathrm{~m}$-unit) restored the spike (Fig. 1e). These data therefore suggest that the hydrolysis of $P_{i}$ leads to $\mathrm{Ca}^{2+}$ release, probably because $P_{i}$ is a far less efficient precipitating anion than is $\mathrm{PP}_{\mathrm{i}}$. Thus $\mathrm{Ca}^{2+}$ initially complexed by $\mathrm{PP}_{\mathrm{i}}$ within the stores will be less tightly bound by the $\mathrm{P}_{\mathrm{i}}$ formed by hydrolysis of $\mathrm{PP}_{\mathrm{i}}$, leading to $\mathrm{Ca}^{2+}$ release from the pools.

The spike recorded in the presence of $\mathrm{PP}_{\mathrm{i}}$, was not prevented

Vol. 282 
by heparin $(50 \mu \mathrm{g} / \mathrm{ml})$ and still occurred when the Ins $(1,4,5) P_{3}$ sensitive pools were kept empty after adding $150 \mu \mathrm{M}-\operatorname{Ins}(1,4,5) P_{3}$ (data not shown); it was therefore unrelated to the spontaneous $\mathrm{Ca}^{2+}$ release from overloaded $\operatorname{Ins}(1,4,5) P_{3}$-sensitive pools that we reported earlier [1]. The rising phase of the spike presumably results from the decreased capacity of $\mathrm{PP}_{\mathrm{i}}$-loaded stores to sequester $\mathrm{Ca}^{2+}$ as the $P P_{i}$ is hydrolysed and the mitochondria continue to leak $\mathrm{Ca}^{2+}$. As the mitochondrial leak progressively decreases, a new increased steady-state free $\left[\mathrm{Ca}^{2+}\right]$ is attained at which the mitochondrial leak is again balanced by $\mathrm{Ca}^{2+}$ uptake into non-mitochondrial stores.

Our data, showing that the progressive hydrolysis of $\mathrm{PP}_{1}$ by a cytosolic pyrophosphatase releases $\mathrm{Ca}^{2+}$ and that this release is unrelated to the spontaneous $\mathrm{Ca}^{2+}$ release from overloaded Ins $(1,4,5) P_{3}$-sensitive pools, warn against possible artefacts when using $\mathbf{P P}_{\mathrm{i}}$ as a precipitating anion. Although the cellular $\mathbf{P P}_{1}$ level increases when the liver is stimulated with a $\mathrm{Ca}^{2+}$-mobilizing hormone [8], it is unlikely that these changes in $\left[\mathrm{PP}_{\mathrm{i}}\right]$ would have a significant effect on the non-mitochondrial $\mathrm{Ca}^{2+}$ stores, not only because the changes in $\left[\mathrm{PP}_{\mathrm{i}}\right]$ are mainly confined to the mitochondria [8], but also because the cytosolic $\mathbf{P P}_{i}$ levels are estimated to be about $5 \mu \mathrm{M}[8]$ and therefore too low to have an effect on the stores.
Supported by the Wellcome Trust (C.W.T.) and Otsuka Pharmaceutical Company (M.J.B.). L.M. is Senior Research Assistant of the N.F.W.O. (Belgium) and was in receipt of an EMBO long-term fellowship.

Ludwig MISSIAEN*, Colin W. TAYLOR $†$ and

Michael J. BERRIDGE*

*AFRC Laboratory of Molecular Signalling, Department of Zoology, University of Cambridge, Cambridge CB2 3EJ, U.K., and + Department of Pharmacology, University of Cambridge, Cambridge CB2 1QJ, U.K.

1. Missiaen, L., Taylor, C. W. \& Berridge, M. J. (1991) Nature (London) 352, 241-244

2. Nunn, D. L. \& Taylor, C. W. (1991) Biochem. Soc. Trans. 19, $206 \mathrm{~S}$

3. Nunn, D. L. \& Taylor, C. W. (1992) Mol. Pharmacol., in the press

4. Irvine, R. F. (1990) FEBS Lett. 263, 5-9

5. Tregear, R., Dawson, A. P. \& Irvine, R. F. (1991) Proc. R. Soc. Lond. Ser. B 243, 263-268

6. Cheek, T. R., Barry, V. A., Berridge, M. J. \& Missiaen, L. (1991) Biochem. J. 275, 697-701

7. Halestrap, A. P. \& Davidson, A. M. (1989) in Anion Carriers of Mitochondrial Membranes (Azzi, A., ed.), pp. 338-348, Springer Verlag, Berlin and Heidelberg

8. Davidson, A. M. \& Halestrap, A. P. (1988) Biochem. J. 254, 379-384

Received 6 September 1991 